\title{
Recycled sewage sludge as part of organic-mineral fertilisers - a comprehensive solution to the use of local raw materials
}

\author{
Maryna Aksylenko, Vitaly Yevdokymenko, Tatiana Tkachenko, Dmytro Kamenskyh, \\ Volodymyr Kashkovsky
}

Department of Organic and Petrochemical Synthesis, V.P. Kukhar Institute of Bioorganic Chemistry and Petrochemistry of the NAS of Ukraine, 02094, UKRAINE, Kyiv, Murmanskaya str, 1, E-mail: ttv13ttv@gmail.com

Combined granular organo-mineral fertilisers with durable action were created. They consist of sewage sludge, ash residues, processing plant waste, humic substances. Obtained granular organomineral fertiliser enabled to enhance mineral nutrition, especially phosphoric, the main grain culture - winter wheat and corn.

Keywords - organo-mineral fertiliser, aeration station, wastewater sludge, sewage sludge, phosphoric nutrition, plant waste, corn.

\section{Introduction}

Nowadays, the problem of municipal wastewater sludge treatment and disposal has high ecological and economic significance [1]. A significant amount (more than 0.5 billion tons) of wastewater sludge have accumulated in the territory of Ukraine. Previously, several directions for their utilisation were proposed [2,3]. The high content of phosphates in sludge, and especially in redundant sludge, allows us to consider such raw material as a promising component of agrochemically effective fertilisers. Unlike nitrogen and other nutrients, fertilisers are the only source for replenishing phosphorus in the soil. The purpose of our work was to create organo-mineral fertiliser (OMF) from sewage sludge, processing plant waste, humic component and study their influence on the ability of plants to use phosphorus of low solubility phosphates of fertilisers and soil.

\section{Materials and methods}

Sewage sludge from Bortnychi wastewater treatment plant, ash residues, processing plant waste, humic substances were used as raw materials for the combined granular organo-mineral fertiliser obtaining. The technological scheme of production of granulated OMF was developed Raw materials and created OMF's were analysed using different physical-chemical methods. Investigation of our OMF's agrochemical efficiency were carried out in vegetation experiment condition on the sandy substrate by routine [4]. The experiment determined the effect of OMF on winter wheat's growth processes, rhizogenic, absorption activity of the root system, in particular, phosphorus compounds from established fertilisers and carry-over of phosphorus plants. Field experiment was putted on dark grey, podzolic soil in Kyiv region according to field research procedure. It was researching the effects of new OMF's preplant on the mineral feeding trends, in particular, phosphorus, corn plant productivity and grain quality ratings (Moscito hybrid).

\section{Results}

It was established that new OMF had any toxic elements. Fertilisers have a size that meets the requirements of modern agricultural engineering for their introduction into the soil (granules diameter 2-6 mm). It was established that the carry-over factor of phosphorus by plants in vegetation experiment increased on $51-79 \%$ for the use of OMF. High adsorption properties of the new granular OMFs components prevent the chemical binding of phosphorus by soil and promote its mobilisation from hard-to-reach soil phosphates and fertilisers. The loose structure of proposed fertilisers contributes to the adsorption and keeping of soil moisture, which must 
inhibit the processes of eolation and soils erosion.Data from field studies with corn on dark grey, podzolic soil have confirmed the high agrochemical efficiency of our fertilisers. Corn's experimental plants for the use of such fertilisers formed a rather powerful root system with increased absorption activity (weight and volume of roots dominated control samples up to 28$41 \%$ ). Introduction to the fertiliser system of the maize hybrid Mosquito OMF-I and OMF-II had affected the improvement of the structural indices of the crop. The one plant's grain yield in the experiment increased up to $19-43 \%$, the weight of 1000 grains - 14-37\%, the weight of the ear $60-82 \%$ compared to the control. Productivity value in the experiment increased up to $5.1 \mathrm{t} / \mathrm{ha}$ and $2.3 \mathrm{t} /$ ha using fertilizers I and II respectively at optimum humidification in the accounting year. The introduction of OMF-I $(0.5 \mathrm{t} / \mathrm{ha})$ into the fertiliser system of maize hybrid Mosquito promoted to the formation of grain with an increased content up to $18.6 \%$ protein compared to control, which introduced only mineral fertilisers. This can be explained by more efficient reutilisation of absorbed nutrients by experimental plants and rapid outflow of photoassimilates from leaves to grains.

\section{Conclusion}

Thus, due to the efficient utilization of plant wastes and wastewater sludge, granulated OMF have been created. The obtaining granulated OMF's used on sod-podzol and grey forest soils, which are the most widespread in Ukraine, is ecologically promising and resource-saving, which can solve complex social problems of many regions. The resulting fertiliser technology can be attributed to local fertilisers: they are made from local raw materials, do not require transportation over long distances and can be used in neighbouring farming.

\section{Acknowledgments}

The experiments and laboratory installation assembling have been funding by Target Complex Program of Scientific Research of NAS of Ukraine from the development of scientific principles of rational use of natural resource potential and sustainable development, project 14, 2015-2019.

\section{References}

[1] N.A. Meshkova-Klimenko, S.M. Epoyan, M.D. Homelya, V.I. Nezdoyminov, V.M. Chernyshev, V.I. Kashkovsky, A.O. Kavits'ka, S.K. Smolin, V.O. Yevdokymenko, Intensyfikatsia technologichnyh protsesiv kompleksnogo ochyschennya stichnyh vod promyslovo-urbanistychnyh tsentriv. Kyiv: LLC « Exclusiv», 2013.

[2] V.I. Kashkovsky, V.A. Yevdokymenko, D.S. Kamensky, T.V. Tkachenko, V.V. Vakhrin, "Complex technology for processing some organomineral waste," Science and Innovation, vol. 13, no. 3, pp. 51-61, 2017. doi: https://doi.org/10.15407/scine13.03.051

[3] V.A. Yevdokymenko, T.V. Tkachenko, D.S. Kamensky, M.D. Aksylenko, and V.I. Kashkovsky, "Sil's'kohospodars'ki ta antropohenni vidkhody - tsinne vidnovlyuvane syrovynne dzherelo," In proc. III Mizhnarodna naukovo-praktychna konferentsiya "Suchasni problemy pryrodnychykh nauk: teoriya, praktyka, osvitni novatsiyi (do 85richchya pryrodnycho-heohrafichnoho fakul'tetu)", Nizhyn, 2018, pp. 297-299.

[4] Z.M. Hrytsaienko, A.O. Hrytsaienko, and V.P. Karpenko, Metody biolohichnykh ta ahrokhimichnykh doslidzhen roslyn i hruntiv [Methods of biological and agrochemical studies of plants and soils]. Kyiv: ZAT «Nichlava», 2003. 